\section{J. Roland Pennock}

J. Roland Pennock died on February 19, 1995 at the Bryn Mawr Hospital, Bryn Mawr, Pennsylvania. The cause of his death at age 89 after a brief illness was termed an overwhelming infection.

Roland Pennock was born in 1906 in Chester County, Pennsylvania, where his Quaker forbears had settled late in the seventeenth century. He attended the George School in Bucks County, Pennsylvania, on whose board he later served for many years, and Swarthmore College, where he was one of the first students in the College's then new Honors program to achieve "Highest Honors." From Swarthmore he went directly to Harvard for graduate work in 1927, and from Harvard he returned to Swarthmore as an Instructor in Political Science in 1929. He was chairman of the department from 1941 to 1970 and retired in 1976 after 47 years on Swarthmore's faculty. On leave from the College Roland served the Social Security Board in 1936-37, the State Department in 1943, and the Philadelphia Regional War Labor Board as a panel chairman, 1943-45. He held visiting teaching appointments at Columbia University (1950) and Harvard University (1953) and, after his retirement, at the University of Pennsylvania, the University of California, San Diego, and the University of Minnesota. He was a member of the American Political Science Association Council, 195355, Vice President of the APSA in 1963 , and served on the Review's Board of Editors in 1965-68 and 1973-76. He was long active in the Social Science Research Council, as chairman of its Committee on Political and Legal Theory and then as board member, each for six years. He was with John Chapman for 23 years editor of the American Society for Political and Legal Philosophy's annual volume, NOMOS, continuing in this role for 14 years after his retirement from Swarthmore; and he was president of the Society in 1968-70.

The authors of this note became Roland Pennock's junior colleagues in 1953, and he was by then an im- mensely respected teacher, primarily for the intellectual rigor and evident integrity with which he taught, but also for the number of students who had experienced his personal concern and assistance in times of difficulty, notwithstanding his apparent austerity. His relations with students matured into friendships with numerous Swarthmore graduates. With junior colleagues on trial in his department it was much the same, except that the teaching was largely by example and that the friendship was apparent from the beginning, if not without early reserve. Implicitly he set demanding standards, characteristically most demanding of himself. In the Swarthmore faculty Roland was regularly a voice of reason, of prudence, of personal and intellectual responsibility, of strong academic standards, of fair dealing, and of respect for others' opinions and equities. For many alumni and colleagues he personified what was best in Swarthmore College and in the academic enterprise in general. As both colleague and teacher he excelled in the colloquy of department, committee, and seminar; his Honors seminars in Political Theory and in Public Law and Jurisprudence were legendary undergraduate experiences at Swarthmore.

Roland thought of himself as a political theorist and of political theory as integral to political science, simply emphasizing certain aspects of the field. There are various ways of doing political theory, or contributing to it, but in Roland's work it was centrally concerned with the clarification and justification of normative positions, with analytic issues relating to the empirical study of politics (e.g., what do we mean, or can we mean, realistically speaking, by "constitutionalism," "the rule of law,", or "representation"?), and with how both normative and analytic theory may illuminate and be illuminated by empirical inquiry. These approaches were deployed primarily in the study and understanding of the politics of liberal democracy. And in their application two closely-related interests or commitments were characteristic: first, an implicit emphasis on deobfuscation and clarity ("clear and simple ideas") insofar as the subject admitted of this; second, a persistent interest in the role of reason, not in the abstract, but mainly in its modes of reasonableness and reasoning together.

This view of theory led to written work in diverse specialties of political science and philosophy, sometimes only in single papers; but there were also a few distinct phases and emphases of the written work. For roughly his first dozen years at Swarthmore Roland's primary teaching fields were public law and public administration, while he awaited the chance to teach theory primarily. Most of his papers in this period were published in law reviews. His first book, Administration and the Rule of Law (1941), pretty much closed this period; its analysis of judicial review of administrative action, while necessarily dated in substance, remains much worth reading for its method. Liberal Democracy: Its Merits and Prospects appeared in 1950. Like some other essays of its time it drew widely on the behavioral sciences for evidence as to both merits and prospects. Its reception was mixed: some critics thought the book mixed social science and normative theory misleadingly and others that its process of argument, while legitimate enough, was not very interesting; still others thought it a magisterial analysis and an important departure in democratic theory.

Roland's other books were the text, Political Science: An Introduction (1964), written with David G. Smith) and Democratic Political Theory (1979). The latter work pretty much distills a lifetime of integral teaching and writing. In it the theoretical approaches and interests identified above come together most notably and, at least in book-length compass, perhaps most successfully in the body of Roland's work.

Without attempting to rehearse the whole of Roland's scholarly contribution, two other projects (as the philosophers say) should be mentioned. One was his critique of majoritarian or "Westminister" institutions and of the associated 
critique of American departures from this model. Its proximate beginning was his classic 1952 paper, "Responsiveness, Responsibility, and Majority Rule." This, with his conviction that theorists and theory gain by participation in empirical work, led him into comparative research on British and American agricultural policy, published in three papers, 1956-62, arguing carefully that in this field American institutions evidently provided more scope for "responsibility," less for direct "responsiveness" to large interest groups. Various other short papers and "comments" through the 1970 s continued to develop this concern, as did some discussions in Democratic Political Theory. Something of the range of Roland's political-science interests is suggested by his foray into the literature of political development, beginning late in the 1950 s (see also his 1956 APSR paper, "Cultural Prequisites to a Successfully Functioning Democracy"). In 1964 he edited a book of lectures given at Swarthmore, Self-Government in Developing Nations. In 1966 he contributed one of his most influential papers, "Political Development, Political Systems, and Political Goods," to World Politics, proposing the notion of "political goods" as a reconception and metric of development.

There were also the various papers and chapters in edited volumes on aspects of democratic theory; indeed, Roland contributed 12 chapters to NOMOS before and during the years of his editorship. While it is impossible to assess his scholarly influence as an editor, it does seem that Roland's way of doing political theory helped make him an effective teacher and scholar as an editor, to the lasting benefit of many colleagues.

Roland was profoundly devoted to the values and methods of liberal democracy and to the reasoned search for truth. Rightly pursued, he believed that these ideals supported each other. Yet, he was keenly aware of the tension between them: a tension that impelled much of his own teaching and writing. He closes with this statement in his Democratic Political Theory:
It used to be thought that it was man's irrationality which posed the greatest threat to democracy. A threat it undoubtedly is, but my contention is that man's rationality, in the sense of pursuit of individual self-interest, presents an equally serious problem. It is to be hoped, then, that this ineradicable self-seeking may be sufficiently moderated by concern for the public interest and by the Kantian (or a similar) ethic of respect for the individual and acceptance of duties toward other individuals compatible with such respect, to make the democratic ideal increasingly practicable and increasingly wide-spread.

For Roland, the political theorist's work could be well or poorly done; but it was never completed.

Charles E. Gilbert

David G. Smith

Swarthmore College

\section{Charles Herman Pritchett ${ }^{1}$}

There must have been a time when I didn't know Herman Pritchett. I just can't seem to remember when. Nevertheless, I can recall the first day we met-an Indian summer afternoon in Chicago, October 2,1955 . He was occupying the chairman's office on the second floor of the old Social Sciences Building. My wife and children and I had arrived the previous day at our graduate student housing, a dingy apartment on the second floor of a rickety fire trap the Navy had forgotten to tear down at the end of World War II. Being only a week out of the Marine Corps, I had had to scrounge around for decent civilian clothing and had found a jacket from my college days, a half-dozen years earlier. Thus correctly attired I marched across the midway to meet Herman. Only later did my wife see a large moth hole in my lapel. I was worried that

\footnotetext{
1 What follows is an edited version of remarks at a memorial service held at the University of California, Santa Barbara, May 31, 1995. I have benefited from the remarks of W. Bruce Richards, Herman's son-in-law and a professor of physics at Oberlin College, and David J. Danelski, Professor Emeritus of Stanford University. Prof. Richards kindly provided the text of several poems that I did not have.
}

Herman had also noticed. After I got to know him, I realized that, if he had seen it, he wouldn't have thought less of me. But I suspect that he did notice, for a few months later he offered me much needed employment as his research assistant.

Those were heady days. The department at Chicago was small by current standards, but it boasted Leo Strauss, David Easton, and Jerome Kerwin in political theory; Quincy Wright and Hans Morgenthau took care of international law and relations; Herman Finer ran comparative politics; Morton Grodzins and Charles Hardin did American politics; Leonard White commanded public administration; Rex Tugwell and Edward Banfield did whatever interested them at the moment; and, of course, Herman was the person in public law. I doubt if any department before or since has had so many great scholars at one time.

The graduate students weren't shabby either: Herbert Storing, Walter Berns, and Martin Diamond defended their dissertations during my first year. James Q. Wilson, Edward Goerner, Edward Levine, and William Gerberding were among those entering then; a year later David Danelski and Aristide Zolberg would join us; after my time, people like Robert Faulkner, Thomas Schrock, Sylvia Snowiss, Sister Candida Lund, and Sotirios Barber would enlist.

Despite intellectual disagreements, most of us poor, very poor, graduate students struggled along well together. Not so the faculty. Wars and rumors of wars were rife in the department; brilliant minds and prickly egos sparked more than ideas. Indeed, crucial to the strategy of passing the written parts of the doctoral examinations was to figure out who would grade which question, for an essay that would please David Easton could infuriate Leo Strauss, one that would gladden Hans Morgenthau's heart could turn Herman Finer's to stone. It is a tribute to Herman Pritchett that those gladiators trusted him to run the department and that aspect of their professional lives. For 13 long years he led them, making contro- 